\title{
Formal and informal ways of learning in employer- provided further training in East and West German enterprises: Results from a large-scale establishment survey
}

\author{
Martin Brussig, Ute Leber**
}

The paper analyses the mix of training forms in employer-provided training in East and West German enterprises with a special emphasis on informal and work-integrated forms of learning. Recent studies have shown that East German enterprises are at least as active in employer-provided training as West German firms. However, these studies are limited to formal ways of further training. Based on a large-scale enterprise survey and ordered-logit regressions, differences in employer-provided further training activities between East and West German enterprises can be shown. In particular, East German enterprises are less active in informal and work-integrated ways of further training.

Der Beitrag untersucht die unterschiedlichen Formen betrieblicher Weiterbildung mit einer besonderen Betonung der informellen und arbeitsintegrierten Formen betrieblicher Weiterbildung im Ost-West-Vergleich. Frühere Studien haben gezeigt, dass ostdeutsche Firmen mindestens so aktiv in betrieblicher Weiterbildung sind wie westdeutsche Betriebe. Jedoch beschränkten sich diese Studien auf formelle Formen betrieblicher Weiterbildung. Basierend auf einer großen Betriebsbefragung und orderedlogit-Schätzungen können Unterschiede in betrieblichen Weiterbildungsaktivitäten zwischen ostdeutschen und westdeutschen Betrieben nachgewiesen werden.

Key words: employer-provided further training; informal and work-integrated learning; human resource management

\footnotetext{
Manuscript received: 10.10 .05 , accepted: 10.06 .06 (1 revision)

** Martin Brussig, Institut Arbeit and Technik Gelsenkirchen. Main research areas: human resource area, transformation issues and labor market policy. Corresponding address: brussig@istge.de

Ute Leber, Institut für Arbeitsmarkt- und Berufsforschung Nürnberg. Main research areas: human resource management, labor demand and employer-provided further training. Corresponding address: ute.leber@iab.de
} 


\section{Introduction}

This paper analyses differences in further training activities between East German and West German enterprises. The analysis includes not only the intensity (diversity and diffusion) of further training, but variance in the mix of further training forms. Special attention is given to formal and informal further training forms. In a second step, we analyse whether organizational characteristics which influence further training activities differ between East and West German enterprises at the micro level., i.e. we analyse whether differences in the diffusion of training forms are caused by a different composition of the population of firms in East an West Germany or whether these differences can be attributed to a different "further training behaviour" of firms.

The key conceptual distinction in this paper is the distinction between formal and informal further training. "Further training activities" are learning activities of individuals aiming at a better understanding of, or coping, with current job tasks. Further training activities are in particular activities which take place after a primary vocational training, or at least after some time of work experience. In this paper, we focus on employer-provided further training only. By formal and informal ways of further training we mean training forms which differ in the the organization of the learning process, its specificity, and the contents of learning (Faust/Holm 2001; Staudt/Kley 1998).

Organization of the learning process: Formal further training refers to organized training measures such as courses or seminars which are conducted outside the regular workplace. By informal further training we mean learning activities which take place outside such organized events and which are often integrated in the process of work itself. However, not only formal, but also informal, learning may be enhanced by organized activities, such as a learning-friendly infrastructure (e.g. learning media).

Specificity of the learning process: This criterion helps to clarify whether a given activity with a "learning effect" aims solely at learning, or whether learning in that given activity is rather a "side effect" embedded in something else, such as work (for an empirical analysis, whether learning or working is dominating in several activities see Grünewald/Moraal 1998).

Contends of what should be learned: Most scholars agree that formal forms of further training are appropriate when experts should learn new technical (explicit) knowledge. In contrast, informal learning is regarded as appropriate when tacit knowledge and social and methodological skills should be learned.

Both formal and informal types types of further training can be organized internally or externally and on an individual or a collective level.

Informal further training is in two aspects important for the skills of employees: First, informal forms of training deal with contents which are often implicit and not accessible for formal ways of learning, such as incremental improvements in 
products, technologies, and work organization. Another example is social skills acquisition; many of them can be aquired better by informal learning "on the job" (Staudt/Kley 1998; Frieling et al. 2000) Second, the ways of learning are different from formal learning. Informal further training is less separated from the work process and the work situation. It is embedded in daily routines. Informal further training may react faster to training needs, and the things learnt can be applied immediately. All these characteristics limit the effects of informal training forms as well. These possible gains of informal learning notwithstanding, there is a broad consensus in the literature that informal learning should not replace formal forms of learning. Rather, both forms should be treated as complementary (Nonaka/Takeuchi 1995; Frieling et al. 2000).

The relations between employer-provided further training activities and organizational learning are far from unidirectional. An organization may "learn" without further training activities, e.g. by recruiting, using its "absorptive capacity" (Cohen/Levinthal 1990), selecting tasks carefully from its environment (Starbuck 1996; March / Sproull / Tamuz 1996). On the other hand, an enterprise can offer further training opportunities without changing its organization. ${ }^{1}$ And, of course, an organization may "learn" as a consequence of further training activities. ${ }^{2}$ Therefore, the consequences of the observed further training activities, and specific consequences resulting from the mix of training forms for East and West German enterprises, can only be explored when organizational learning can be observed independently from individual learning.

The questions of training and further training are ,for East German firms, of specific importance. Despite the unification - the German way of transformation from state socialism to a market economy -, Germany still is divided in its socioeconomic performance. Indicators can be found not only at the macrolevel, such as unemployment, migration and population decline, but at the micro-level of enterprises as well.

Although there are many success stories, the average East German enterprise has less innovations and exports and is less efficient than its western counterpart. A crucial element, is the human capital of employees in East German enterprises. From 1990 onwards, a huge demand for further training emerged, and soon appropriate structures of training institutions have been created and the economic and labor market policy adjusted accordingly (Andretta/Baethge

1 Weick / Wesley (1980: 440) describe organizational learning as an "oxymoron": "To learn is to disorganize and increase variety. To organize is to forget and to reduce variaty." Others, such as March/Olson (1976) or Argyris/Schon (1978) treat organisational learning as "individual learning in an organisational context" (Weick/Wesley 1980: 441).

2 A further problem in relating further training activities to organisational learning is that "learning" refers to both an outcome and a process, while "further training activity" is an activity (or a "process") without strong assumptions about the result. 
1996). As a result, participation in further training activities was not only higher for East German individuals (employed and unemployed), but for East German enterprises as well (see table 1).

Table 1. Further training in East and West German enterprises in 1997-2003, Enterprises with employer-provided further training in \%:

\begin{tabular}{|l|l|l|l|l|l|}
\hline & $\mathbf{1 9 9 7}$ & $\mathbf{1 9 9 9}$ & $\mathbf{2 0 0 0}$ & $\mathbf{2 0 0 1}$ & $\mathbf{2 0 0 3}$ \\
\hline East German enterprises & 39 & 42 & 40 & 37 & 44 \\
\hline West German enterprises & 37 & 38 & 36 & 36 & 41 \\
\hline
\end{tabular}

Source: IAB Establishment panel, own calculations

However, despite the training efforts in East German enterprises, their performance is still clearly behind West German standards (Schäfer/Wahse 2001; Czarnitzki 2003; and appendix). This needs explanation, bearing in mind an often assumed positive correlation between further training activities and corporate performance. Contrasting with expectations both from economic and labor market policy as well as from economic theory, a broad engagement in further training would not improve productivity, exports and innovations substantially, at least not to an extent which would narrow the performance gap to West German firms.

The paper attempts to come closer to that puzzle not by investigating the relationship between performance and further training of firms, ${ }^{3}$ but by comparing the activities firms undertake in their further training from East and West Germany. What happens within the firms when firms register- either by self reporting or by observation from external observers - as providing further training?

There are three initial arguments in favor of the hypotheses that East and West German enterprises have a different mix of learning forms, and that East German enterprises use less informal ways of further training. The first argument is a methodological one. Earlier studies focused on formal forms of further training (Bellmann/Düll 1998; Wilkens/Leber 2003). These studies generalized their findings to employer-provided training at large, i.e. including informal training, by implication and not by specific empirical analysis.

The second argument concerns the "supply side" of further training, i.e. the infrastructure and staff for further training outside enterprises. This includes, for

3 The relation between further training and performance is, of course, far from clear. First, the direction of the causation might be reversed (Bellmann/Büchel 2001, in contrast: Zwick 2004). Second, even if further training has a positive impact on performance (and not the other way around), it is not clear whether the impact is strong enough in the East German context to improve performance drastically' 
instance, chambers of commerce, industry associations, unions or specialized commercial service enterprises. This further training infrastructure was set up in the beginning of the transformation process, and enterprises (and individuals, whether employed or unemployed) were subsidized when using their services, i.e. when they bought participation at training courses. Much of active labor market policy has been devoted to further training. Maybe the widespread activities of East German enterprises in formal forms of further training do not reflect strategic decisions within the enterprises, but rather a reaction to favorable external opportunities.

The third argument takes up a discussion which also emerged early in the transformation debate. Studies about the mind-set of East German managers have shown their narrow focus on technological questions regarding products and production processes ( Meinerz 1996). Matched-pair comparisons of production plants in East and West Germany (Mallok 1996; Mallok/Fritsch 1997) have shown that, even with similar technologies, superior work organisation and handling of technologies enabled West German enterprises to be more efficient. Inter-firm relations in East Germany are less characterized by high trust relations within networks, as is typical for the "German capitalism" (Streeck 1992), but rather by hierachical networks with external headquarters and East German enterprises in a dependent position striving for entrepreneurial autonomy with low trust towards local competitors (Semlinger 1992; Bluhm 1997). All this points to a neglect of implicit knowledge and informal relations.

Due to the neglect of informal knowledge of East German managers in the early years of the transformation, the "pull effects" of the external further training infrastructure in East Germany and the one-sidedness of existing studies about further training which appear as a consequemce, it is not known whether East and West German firms actually differ in their mix of training forms.

\section{Imperical analysis}

\subsection{Data}

To test the hypothesis that East and West German enterprises differ from each other in their formal and informal further training activities, it is necessary to rely on a survey which contains a wide variety of learning forms, including informal and formal forms of further training. The survey "Competence development in enterprises" is appropriate, because it puts an emphasis on informal forms as training as well as on formal forms. This survey includes 
enterprises with between 20 to 999 employees from different branches. ${ }^{4}$ Address data were obtained from the Federal Employment Office (Bundesagentur für Arbeit) for 8,701 enterprises. Additionally addresses from 1,300 very small enterprises (5 to 19 employees) from selected industries ${ }^{5}$ have been included. Computer-aided telephone interviews (CATI) were carried out by Zentrum für Sozialforschung Halle (zsh) between August and December 2002. Altogether 1,788 interviews have been collected. The return ratio thus amounts to $22 \%$.

The original aim of this investigation was to analyze the full range of employerprovided forms of learning, including, for example,. human resource strategies and recruiting behavior. However, the focus of this paper is on employerprovided training including formal and informal forms.

The enterprises were asked whether they offer different kinds of the further training to their employees. The specific question was "Please tell us whether, during the last 12 months, the employees in your enterprise have taken part in the following further training measures: (a) internal courses, training courses or seminars, (b) external courses, training courses or seminars." Next, the question followed: "Learning may occur beyond organized forms of training as well, in particular by exchanging experiences at the workplace between employees. Please tell us for which groups of employees several forms of learning are important." At this point, several forms of informal training have been mentioned in the interview (information and instruction by a supervisor, mentorship, quality circles, job rotation, team work, reading of professional or technical literature, congress visits and attending industry fairs ${ }^{6}$; see table 2 ). This specific verbal expression attempted to communicate that it is not the primary interest for the researchers whether there is or is not something like "job rotation" or "team work", but whether these forms of work organizing are "important for learning" in an enterprise. Only if these items are regarded as important for learning, they should be chosen by the interviewee.

It should be mentioned that by formulating questions in this way we do not know whether employees actually learnt something while participating in these

4 The branches which were not included are "education / instruction", "interest representation / associations / churches and other religious associations", and "private households and public administration / defense / social security". These branches have been omitted because the organizations lack typical characteristics of enterprises, such as capital utilization, profit orientation, and restriction of liability.

5 These branches are "trade / repair", "restaurants / hotels", "health / social welfare", "data processing and data banks", "legal, tax and economic consultancy, advertisement / market research" and "Renting of mobile things / other services (predominantly for enterprises)". These industries are in particular shaped by small enterprises.

6 Additionally, "computer based training" was mentioned here. It will not be included in this analysis because its allocation to formal or informal forms of training is not clear. 
learning forms. Nor do we get to know whether they applied their newly acquired knowledge and skills. What we learn is whether enterprises used several training forms as a platform for their employees to learn. We cannot know why they did so - a perceived need for new knowledge and skills, imitating best practices in other enterprises, a firm specific learning culture, or demands on behalf of the employees, to name but a few possible reasons - but we can assume that the enterprises found it appropriate to offer these opportunities.

Table 2. Forms of formal and informal further training

\begin{tabular}{|l|l|l|l|l|l|}
\hline \multicolumn{1}{|c|}{ Formal further training } & \multicolumn{4}{|c|}{ Informal further training } \\
\hline Internal & External & \multicolumn{2}{|c|}{ Internal } & \multicolumn{2}{c|}{ External } \\
\hline & & Individual & Collective & Individual & Collective \\
\hline Internal & External & - Information, & - Quality & - Reading of & - Congresses, \\
courses, & courses, & instruction & circles & professional / & industry \\
classes etc. & classes etc. & by & - Job & technical & fairs etc. \\
& & supervirsor & rotation & literature & \\
& & - Mentorship & - Team work & & \\
& & & & \\
\end{tabular}

Distribution of the enterprises in groups of further training intensity

\begin{tabular}{|l|l|c|c|}
\hline Groups & $\begin{array}{l}\text { Definition of Groups } \\
\text { by Further Training } \\
\text { intensity } \\
\left(\mathrm{FT}_{\text {Formell }} \text { and } \mathrm{FT}_{\text {Informell }}\right)\end{array}$ & $\begin{array}{c}\text { Formal Further } \\
\text { Training }\end{array}$ & Informal Further Training \\
\hline in $\%$ & in $\%$ & in $\%$ \\
\hline Without... rarely & $0 \ldots>=12.5$ & 12 & 6 \\
\hline Small & $>12.5 \ldots>=33.4$ & 20 & 81 \\
\hline Middle & $>33.4 \ldots<=62.5$ & 28 & 16 \\
\hline High & $>62.5 \ldots<=83.4$ & 20 & 3 \\
\hline Very high... all & $>83.4 \ldots<=100$ & 21 & $<$ \\
\hline
\end{tabular}

Source: zsh: Competence development in German enterprises (weighted information).

\subsection{Methodology}

In a first step we analyze the diffusion of both forms of learning in East and West German enterprises. We present - besides some descriptive findings results of multivariate regressions which include formal and informal further training as dependent variables and the location of the enterprise amongst some other variables as an independent variable.

Once the first question about the significance of the regional location for the further training activities is answered, we ask, in a second step, what accounts for these differences, and how they can be explained. Again we use regression techniques, but unlike in the first step, separate models are estimated here for 
East and West Germany including the same independent variables. Differences between East and West German enterprises in direction, strength or significance of the independent variables hint as to the reasons for differences in the further training activities of the enterprises.

As dependent variable we calculate further training intensity. The further training intensity serves as an indicator as to how much forms of further training are used in an enterprise, and how much these forms of further training are diffused among the employees in the enterprise. For example, an enterprise might use a wide variety of learning forms, but only for their managers. Another enterprise would use a wide variety of learning forms for their managers and skilled workers, but not for their unskilled workers. The diffusion of learning forms would be greater in the second example than in the first, and it would be even greater if unskilled workers were to be included. The indicator "further training intensity" includes both dimensions, variety and diffusion of learning forms.

For each enterprise, the further training intensity is calculated separately for formal and informal forms of further training. For this purpose we have created an index for every enterprise which sets the intensity value of 100 for formal (informal) further training if,in this enterprise, all forms of formal (informal) further training are carried out for all employees' groups available in the enterprise, and a value of 0 if no employees' group carry out any form of formal (informal) education (see (1a) and (1b)). Altogether two forms of formal and seven forms of informal further training (see section 2) as well as four groups of employees were differentiated; management and employees with university degree, skilled white-collar employees, skilled blue-collar worker, unskilled (white and blue collar) workers). By far the most of the enterprises use different forms of further training only in selected employees' groups (Brussig/Leber 2005).

$$
F T_{\text {Formal }}=\frac{F L_{M U D}+F L_{S W C}+F L_{S B C}+F L_{U}}{N G \cdot 2} \cdot 100
$$


(1b)

$$
F T_{\text {Inforal }}=\frac{I L_{M U D}+I L_{S W C}+I L_{S B C}+I L_{U}}{N G \cdot 7} \cdot 100
$$

$\mathrm{FL}$ - number of applied formal forms of learning in the respective group

$\mathrm{IL}$ - number of applied informal forms of learning in the respective group

$\mathrm{NG}$ - number of groups of employees in the company (management/university degree; skilled white collar; skilled blue collar; unskilled)

There is a problem inherent in this index when it is used as an endogenous (or dependent) variable. Due to a different denominator of $\mathrm{FT}_{\text {Formal }}$ and $\mathrm{FT}_{\text {Informal, }}$ both indicators yield a different number of values. However, for a comparison of regression coefficients it is necessary to have dependent variables which are similar in their structure, i.e. which have the same number of values. Therefore, we transformed both indicators into the same scaling by assigning each case (enterprise) in one of five groups of further training. These groups range from "without ... rarely" to "very much" further training activities. ${ }^{7}$ Quasi-metric variables have thus been transformed into ordinal variables. This leads to two scales of gradated intensity of further training (each for the formal and informal forms of learning) (see table 3).

Table 3. Further training intensity (mean), East and West German enterprises

\begin{tabular}{|l|c|c|}
\hline & $\begin{array}{l}\text { Formal further } \\
\text { training }\end{array}$ & Informal further training \\
\hline $\begin{array}{l}\text { West German } \\
\text { enterprises }\end{array}$ & 63,2 & 45,5 \\
\hline $\begin{array}{l}\text { East German } \\
\text { enterprises }\end{array}$ & 60,8 & 43,2 \\
\hline Sign. T-Test & 0,014 & 0,080 \\
\hline
\end{tabular}

Source: zsh: Competence development in German enterprises (weighted information).

Compared to other ways of measuring employer-provided further training, our index has some specifics. It is very common, for instance, simply to count whether enterprises provide further training or not. In contrast, a ranking of

7 Two criteria have been applied in the definition of the margins for each group: First, the margins should be the same for $\mathrm{FT}_{\text {Formal }}$ and $\mathrm{FT}_{\text {Informal }}$ (margins are given in table 3). Second, the number of values should be equally distributed over the whole range of values of $\mathrm{FT}_{\text {Formal }}$ and $\mathrm{FT}_{\text {Informal }}$, respectively. In other words, the range in each subgroup should be of the same width, i.e. the group "small" should contained as many values (or be of the same range or width) as the group "high". 
further training intensity, as it is used here, provides more information. Another common way to measure is to count the employees of an enterprise who take part in further training. However, the survey we use here does not contain this information, since it is difficult to count employees who take part in informal, implicit and work-integrated forms of learning.

The dependent variables can be understood as ranked (ordinal) variables. In ordinal variables, the distances between the values are neglected. Different methods are available for the modeling of ordinal dependent variables (Kohler / Kreuter 2001). Here, we have decided to use the estimation of Ordered LogitModels to examine the influence of the regional location (East or West German enterprise) and other dimensions on the formal and informal further training intensity. ${ }^{8}$

\subsection{Does the location of an enterprise exert an influence on the intensity of formal and informal further training?}

\section{Descriptive results}

The index for further training activities - before grouping into five ranked groups - differs for both kinds of further training activities. It is slightly higher for West German enterprises; the difference between both means being significant (see table 3).

A closer look not only at the means, but also at the distribution over all five groups, shows that East and West German firms are quite similar, in particular with respect to their formal training intensity (see table 4). In each case, $21 \%$ of firms are in the highest group of formal further training (external courses and seminars as well as internal courses and seminars are used by all or nearly all groups of employees in the firm). The largest group (29\% and $26 \%$, respectively) is in both cases the middle group. There are similarities between East and West German firms in the diffusion of informal further training as well. In both cases, nearly half of the enterprises belong to the middle group of informal further training intensity.

The most remarkable difference is that East German enterprises are to be found somewhat more frequently in the two lowest groups of informal further training intensity. This is a first but small sign that East German firms in general use informal forms of training less often - at least there are more firms in East Germany which do so - as could be expected from the discussion about the further training behavior (see above).

However, from the distribution alone it cannot be concluded that East German enterprises pursue clearly less informal further training and, at the same time,

8 Ordered Probit estimations, which we have also tested, lead to very similar results. 
just as much formal further training, because this observation can be distorted by compositional effects of both partial samples. We examine this with the help of multivariate estimations under inclusion of control variables.

Multivariate estimations. As already mentioned above, in the following part,we first present the results of multivariate estimates in which East and West German enterprises are lumped together. Since in the first step we are concerned about the potential influence which the location of an enterprise (East vs. West Germany) exerts on the intensity of the formal or informal further training, the East-West affiliation of the enterprises represents the central independent variable, whereby we treated the Berlin enterprises as East German enterprises. ${ }^{9}$ Beside this dummy-variable we include several control variables, such as the size of enterprise and the branch affiliation, the employee structure, innovations, characteristics of the work organization and HRM problems (recruiting problems and labor turnover).

Table 4. Distribution of the groups of further training intensity in East and West German enterprises

\begin{tabular}{|l|l|l|l|l|}
\hline Groups & \multicolumn{2}{|c|}{ West } & \multicolumn{2}{c|}{ East } \\
\hline & Formal & Informal & Formal & Informal \\
\hline & in $\%$ & in $\%$ & in $\%$ & in \% \\
\hline $\begin{array}{l}\text { Without } \\
\text { scarcely }\end{array}$ & 10 & 5 & 15 & 6 \\
\hline Small & 21 & 27 & 18 & 31 \\
\hline Middle & 29 & 47 & 26 & 46 \\
\hline High & 20 & 17 & 19 & 14 \\
\hline Very high all & 21 & 3 & 21 & 3 \\
\hline
\end{tabular}

Source: zsh: Competence development in German enterprises (weighted information)

It can be expected from all these control variables that they exercise an independent influence on the further training behavior of the enterprises this also being empirically demonstrated by different studies (Brussig/Leber 2005; Gerlach/Jirjahn 2001; Bellmann/Düll/Leber 2001). Table 5 contains information about how these variables have been operationalized and the distribution of the variables within our sample.

The regression results (see table 6) show that, under the control of other variables, the regional location (East or West Germany) of the company has an influence on informal further training activities, but not on formal further training activities. The regression confirms the bivariate result (see table 3 ) only for informal further training activities and rejects it for formal further training activities. As the significant negative sign indicates, East German enterprises are

9 The results are stable concerning the treatment of enterprises from Berlin as East or West German enterprise. 
less active in the informal further training than West German enterprises. The coefficient is not significant for formal further training. This confirms previous studies which could not find significant differences in the further training activities of the East and West German enterprises. It should be mentioned here that the "structural variables" (size of enterprise, sector and status of the enterprise) "cause" the significant difference. As long as it is not controlled for these variables, significant differences could not be observed in the formal as well as in the informal further training between East and West German enterprises.

The remaining variables should be discussed here only briefly (Brussig/Leber 2005):

For the characterization of the employee structure, the share of skilled workers, fixed-term contracts and part-timers were considered. From various studies we know that companies with a large proportion of skilled workers are more active in further training (Gerlach/Jirjahn 2001; Bellmann/Düll/Leber 2001). From a human capital point of view, this is easy to understand. Skilled employees have been already in the past been "willing and able to learn", and therefore a readiness for acquiring additional knowledge and skills can be assumed (Düll / Bellmann 1999; Gerlach / Jirjahn 2001). Moreover, there is a micro-political argument, pointing to the fact that participation in employer-provided further training indicates the importance of the participating persons for the enterprise and the power of skilled employees to negotiate for employer-provided further training (Martin/Behrends 1999).

In several previous studies, a positive correlation between further training and skilled employees was observed for formal further training. This correlation can be found in our analysis as well. In contrast, the correlation between employee structure and participation in informal training is not clear. On the one hand, access barriers to informal training are lower, training costs are less visible and explicit, which should result in a broader participation of low-skilled employees, i.e. a weaker or non-existent correlation between participation in informal further training and skill structure of the workforce. On the other hand, however, available results did not confirm these considerations (Dobischat et al. 2003; Brussig/Leber 2004).

According to these studies, participation in informal further training is stronger when the proportion of skilled employees is higher. This result can be confirmed by our analysis. The coefficient for informal training intensity is lower than the coefficient for formal training intensity, but it is still significantly positive. A possible explanation is that enterprises address, in their further training activities formal as well as informal "core groups" of employees, to which low-skilled employees do not belong. 
Table 5. Description of the independent variables

\begin{tabular}{|c|c|c|c|}
\hline Variables & Description & Mean & \\
\hline & & West & East \\
\hline Location & $0=$ West, $1=$ East & & \\
\hline $\begin{array}{l}\text { Size of enterprise/ } \\
\text { Organization Status: } \\
-\quad \text { Size of enterprise } \\
-\quad \text { Status }\end{array}$ & $\begin{array}{ll}\text { - } & \text { Number of Employees (log. }) \\
\text { - } & \text { Enterprise is a part of a larger company or a } \\
\text { group of firms }(0=\text { no, } 1=\text { yes })\end{array}$ & $\begin{array}{l}2.95 \\
0.30\end{array}$ & $\begin{array}{l}2.89 \\
0.27\end{array}$ \\
\hline $\begin{array}{l}\text { Employee structure: } \\
\text { - } \quad \text { Proportion of skilled } \\
\text { empl. } \\
\text { - } \quad \text { Proportion of } \\
\text { employees with fixed } \\
\quad \text { term contract } \\
-\quad \begin{array}{l}\text { Proportion of part } \\
\text { time empl. }\end{array} \\
\end{array}$ & $\begin{array}{l}\text { - Proportion of the executives / highly } \\
\text { qualified, specialized technical and skilled } \\
\text { employees of all empl. within the enterprise } \\
\text { - Proportion of the employees with fixed term } \\
\text { contacts of all empl. within the enterprise } \\
\text { - Proortion of the part time employees from the } \\
\text { total employees of all empl. within the } \\
\text { enterprise }\end{array}$ & $\begin{array}{l}0.82 \\
0.04 \\
0.21\end{array}$ & $\begin{array}{l}0.86 \\
0.07 \\
0.16\end{array}$ \\
\hline $\begin{array}{l}\text { Innovations: } \\
-\quad \text { Technological } \\
\text { innovations } \\
-\quad \text { Product innovations } \\
-\quad \text { New materials } \\
-\quad \text { Organisational } \\
\quad \text { changes }\end{array}$ & $\begin{array}{l}\text { Substantial improvement of the technical } \\
\text { equipment in the last three years } \\
\text { - Implementation of new product/achievements } \\
\text { in the last three years } \\
\text { - Introduction of new materials in the last three } \\
\text { years } \\
\text { - Introduction of new forms of work in the last } \\
\text { three years } \\
0=\text { no, } 1=\text { yes }\end{array}$ & $\begin{array}{l}0.57 \\
0.64 \\
0.13 \\
0.22\end{array}$ & $\begin{array}{l}0.55 \\
0.63 \\
0.14 \\
0.21\end{array}$ \\
\hline $\begin{array}{l}\text { Work requirements / - } \\
\text { organisation: }\end{array}$ & $\begin{array}{ll}- & \text { Willingness and ability to cooperate } \\
\text { - } & \text { Holistic work organization } \\
\text { - } & \text { Taking responsibility } \\
\text { - } & \text { Participating in decisions } \\
\text { - } & \text { Contributing to innovations } \\
\text { - } & \text { Employability / career development } \\
- & \text { Information what happens in the enterprise } \\
- & \text { Autonomy } \\
0=\text { no, } 1=\text { yes }\end{array}$ & $\begin{array}{l}0.64 \\
0.57 \\
0.38 \\
0.27 \\
0.44 \\
0.60 \\
0.34 \\
0.46\end{array}$ & $\begin{array}{l}0.57 \\
0.62 \\
0.30 \\
0.22 \\
0.46 \\
0.51 \\
0.35 \\
0.40\end{array}$ \\
\hline $\begin{array}{l}\text { HR problems } \\
-\quad \text { Labour turnover } \\
-\quad \text { Recruitment }\end{array}$ & $\begin{array}{l}\text { Enterprise has problems with labour turnover } \\
\text { - Enterprise has problems with the recruitment } \\
\text { of the executives and /or specialists } \\
0=\text { no, } 1=\text { yes }\end{array}$ & $\begin{array}{l}0.33 \\
0.75\end{array}$ & $\begin{array}{l}0.25 \\
0.76\end{array}$ \\
\hline Sector & $\begin{array}{l}7 \text { sectors (manufacturing industry, commerce, } \\
\text { credit / insurance, industry services, health-/ } \\
\text { social welfare, others. Services, reference: } \\
\text { construction industry) }\end{array}$ & & \\
\hline
\end{tabular}

Source: zsh: Competence development in German enterprises (weighted information), own calculations.

Human capital theory and micro-political considerations can also be referred to in explaning the correlation between further training intensity (formal and 
informal) and the proportion of fixed-term and part-time employees. Human capital theory argues that the incentive for enterprises to invest in further training is less for fixed-term employees and part-timers, because the yields of the investments last for a shorter period than for regular employees.

Moreover, from a micro-political point of view it can be argued that contingent workers have smaller bargain power and are thus in a weaker position to negotiate for further training. Both arguments apply mostly for formal further training. Assuming that decision makers in enterprises are less explicit in their cost considerations with respect to informal further training, differences between contingent employees and regular employees should be less pronounced for the participation in informal further training. However, empirically, only the relation between the proportion of part-timers and formal further training is, as expected, significant negative.

In addition to the structure of the workforce, we included several indicators about innovation activities of the enterprise. Generally, it is agreed that innovations cause a need for new skills, which in turn lead to further training. Therefore a positive correlation between further training and innovation can be assumed. It remains unclear whether this correlation exists for formal further training as well as for informal further training.

For instance, innovations in technologies require new knowledge as to how to operate new machinery and technologies, which can be acquired by formal further training. However, recent studies in innovation research emphasized "intelligence" in the use of technologies and thus the importance of implicit knowledge and expertise, which might lead to informal further training as well. In our analysis, the introduction of new technologies exercises a significant positive effect on the intensity of informal further training, but not on the intensity of formal further training. The coefficient is not significant in the estimations of formal further training. Other aspects of innovations, such as "introduction of new materials", "introduction or advancement of new products" as well as "realization of organizational changes", however, exercise a significantly positive influence on the intensity of the formal as well as the informal further training. This underlines the general importance of further training (formal and informal) for innovations. ${ }^{10}$

Among the variables which characterize the organization of work and work requirements, most have a significantly positive effect on informal further training. For instance, enterprises are more active in informal further training activities when they demand to cooperate closely with their employees. For formal further training activities, however, this indicator - willingness and

${ }^{10}$ Interview partners have been asked, whether these innovations took place in their enterprises during the last three years (multiple answers possible). 
ability to cooperate - is not significant. Likewise, several aspects of autonomy and responsibility at the workplace correlate significantly with informal and work-integrated further training activities, but not with formal further training activities. An indicator for "employability", namely "caring for individual career development" does not correlate significantly with the extent of informal as well as formal further training activities. An explanation could be that enterprises regard employability as a responsibility of the individual employee, but not of the human resource strategy of the firm.

Two kinds of human resource problems have been included in our analysis: Problems with recruitment and problems with labor turnover (fluctuation). The empirical analysis shows that enterprises which have problems with labor turnover are less active in employer-provided further training. This applies for formal as well as for informal learning forms. From a human capital point of view such a result seems plausible, because for these firms investment in human capital is not attractive when employees leave the enterprise and take the human capital investments with them.

In enterprises with recruitment problems, neither the intensity of the formal, nor that of the informal further training is higher than in those companies without recruitment problems. This is somewhat surprising (Düll/Bellmann 1998), because it can be assumed that enterprises with problems on the external labor market try to cover their need for skills by improving the existing workforce in the enterprise by employer-provided training. Another reason for more activities in employer-provided training in firms with recruitment problems is that firms could use further training as a marketing instrument to attract human resources from the labor market.

Finally, the size of the enterprise has an influence on formal further training activities as well as - to a lesser extent - on informal further training activities. One of the arguments in favor of informal further training is that enterprises which cannot afford formal further training activities - in particular, SMEs could use informal forms of learning instead. The result here shows some empirical justification: There is a size-dependency in formal and informal further training activities, but it is not as pronounced for informal as for formal forms of further training.

\subsection{Different influences on formal and informal further training in East and West German enterprises?}

In the section above, we have shown that the location of an enterprise has a significant influence on the intensity of informal and work-integrated, but not on formal further training. This section analyses in more detail, whether there are differences in the factors which influence the intensity of formal and informal further training between East and West German enterprises. For that purpose we repeat our multivariate regressions separately for East and West German firms. 
With the exception of the variable "location", which is redundant now, the same explanatory variables are included.

Among the results (see table 7), only some will be selected for a brief discussion. There are some differences between East and West German enterprises in the influence innovation activities have on further training. In particular, West German enterprises with innovations emphasize informal and work-integrated further training and do not pay special attention to formal forms of further training (compared to non-innovating enterprises in West Germany), with one exception (organizational changes). Innovating East German enterprises, in contrast, use the full range of further training, including formal as well as informal forms of learning.

With respect to the structure of the workforce it is worth mentioning that there is a correlation between the proportion of skilled employees on the one hand and formal further training activities on the other in both East and West German firms. However, a similar correlation for informal and work-integrated further training can be observed in West German enterprises only. In East German firms, there is no relation between the proportion of skilled employees and the intensity of informal further training.

Finally it can be observed that West German enterprises which reported problems in finding skilled employees on the external labor market, are more engaged in formal further training, but not in informal further training. This corresponds to the considerations discussed in section 3.2: Enterprises with recruitment problems will probably invest rather in formal than in informal further training because, first, improving skills of those already employed can be an alternative to recruiting new employees, and, second, employer-provided further training activities can serve as "human resource marketing" and contribute to an image as an attractive employer for applicants from the external labor market. As the results show, these considerations apply for West German enterprises only, but not for East German firms. This could point to the fact that, due to a particular strong position of East German firms on local labor markets, they regard further training as an instrument for human resource marketing as unnecessary. This is explained also by the less developed human resource strategies of East German firms in general (Lang 1995; Lang/Wald 2001; Brinkmann 2001). 
Table 6. Determinants of formal and informal further training intensity

\begin{tabular}{|c|c|c|}
\hline 1 & 2 & 3 \\
\hline & $\begin{array}{l}\text { Intensity of formal } \\
\text { further training }\end{array}$ & $\begin{array}{l}\text { Intensity of informal further } \\
\text { training }\end{array}$ \\
\hline Location of the enterprise & -0.066 & $-0.186^{* *}$ \\
\hline $\begin{array}{l}\text { Structure of the workforce: } \\
\text { - } \quad \text { Proportion of skilled empl. } \\
\text { - } \quad \text { Proportion of employees with } \\
\text { fixed term contract } \\
\text { - } \quad \text { Proportion of part time empl. }\end{array}$ & $\begin{array}{l}0.780 * * * \\
0.236 \\
-0.452 *\end{array}$ & $\begin{array}{l}0.592 * * \\
0.357 \\
0.227\end{array}$ \\
\hline $\begin{array}{l}\text { Innovations: } \\
-\quad \text { Technological innovations } \\
-\quad \text { New materials } \\
-\quad \text { Product innovations } \\
-\quad \text { Organisational changes }\end{array}$ & $\begin{array}{l}0.131 \\
0.255^{*} \\
0.305^{* * *} \\
0.642^{* * *}\end{array}$ & $\begin{array}{l}0.300^{* * *} \\
0.388 * * * \\
0.403 * * * \\
0.870^{* * *}\end{array}$ \\
\hline $\begin{array}{ll}\text { Work requirements /-organization: } \\
\text { - } \quad \text { Willingness and ability to } \\
\text { cooperate } \\
\text { - } & \text { Holistic work organization } \\
\text { - } & \text { Taking responsibility } \\
- & \text { Participating in decisions } \\
- & \text { Contributing to innovations } \\
- & \text { Employability / career } \\
& \text { development } \\
- & \text { Information what happens in } \\
& \text { the enterprise } \\
- & \text { Autonomy }\end{array}$ & $\begin{array}{l}0.056 \\
-0.005 \\
0.034 \\
0.360 * * * \\
0.150 \\
-0.015 \\
0.306^{* * *} \\
0.155\end{array}$ & $\begin{array}{l}0.264 * * \\
-0.102 \\
0.619^{* * *} \\
0.645^{* * *} \\
0.319^{* * *} \\
0.035 \\
0.208^{* *} \\
0.171\end{array}$ \\
\hline $\begin{array}{l}\text { HR problems } \\
-\quad \text { Labour turnover } \\
-\quad \text { Recruitment } \\
\end{array}$ & $\begin{array}{l}0.195 \\
-0.165^{*} \\
\end{array}$ & $\begin{array}{l}0.157 \\
-0.187 * \\
\end{array}$ \\
\hline $\begin{array}{l}\text { Size of enterprise / organizational } \\
\text { status: } \\
\text { Size (no. of empl. (log.)) } \\
\text { Status }\end{array}$ & $\begin{array}{l}0.311^{* * *} \\
0.160\end{array}$ & $\begin{array}{l}0.175^{* * *} \\
0.186^{*}\end{array}$ \\
\hline $\begin{array}{l}\text { Sector: } \\
7 \text { sectors included }\end{array}$ & yes & yes \\
\hline $\mathrm{N}$ & 1,587 & 1,587 \\
\hline Pseudo-R ${ }^{2}$ & 0.068 & 0.1229 \\
\hline
\end{tabular}

Dependent variable: Employer-provided further training intensity for forms of formal learning (column 2) and informal and work-integrated learning (column 3). Ordered probit. Software: STATA.

$* * *, * *, *$ significance on $1 \%-, 5 \%-, 10 \%$ levels.

Source: zsh: Competence development in German enterprises, own calculations. 


\section{Conclusion}

Two questions have been analyzed in this paper: (1) Do East German firms provide different ways of learning in their further training activities, do they, in particular, focus on formal forms of further training and neglect informal and work-integrated forms of further training, compared to West German enterprises? and (2) are the factors which influence the further training intensity different between East and West German enterprises?

Several studies have shown that East German enterprises provide as much further training as West German enterprises do. However, these studies are limited to formal ways of further training. Although there are some exceptions (Gerlach/Jirjahn 2001; Bellmann/Düll/Leber 2001), most of these studies are descriptive and might be distorted by composition effects of different firm populations in East and West Germany. Our analysis shows that East and West German firms are not different in their formal further training activities, but that there are differences in the intensity of informal and work-integrated further training. In these learning forms, West German firms are more active. Given the arguments presented at the outset relating to a neglect of informal knowledge of East German managers in the early years of the transformation and the "pull effects" of a broad external further training infrastructure in East Germany, this result is not completely surprising.

Concerning the second question whether further training "works" in the same way in East and West German enterprises, likewise some differences emerged, which appeared, in particular, in innovation behavior. For East German enterprises which reported innovations concerning the introduction of new technologies or the use of new materials in the enterprise, the development or improvement of new products or organisational changes, provide a whole range of further training activities, while innovating West German enterprises put an emphasis on informal forms of further training.

Can these differences in the further training behaviour and in particular the relative neglect of informal further training in East German enterprises contribute to explain the persistent productivity gaps between East and West German enterprises? The empirical results make such an hypothesis plausible. However, to come from "plausibility" to empiricallly stable arguments, two additional steps are necessary: To understand the relation between further training activities and firm performance, more information would be needed, especially performance indicators. An enlarged conceptual frame would be also required, because the relations between further training activities and firm performance can be manifold and, causality between further training and firm performance might be reversed. Thus contexts outside the firm and the culture inside the firm influence the transformation of individual learning into organisational change. 
Table 7. Determinants of formal and informal further training intensity in East and West German firms

\begin{tabular}{|c|c|c|c|c|}
\hline \multirow[b]{2}{*}{1} & \multicolumn{2}{|c|}{$\begin{array}{l}\text { Intensity of formal further } \\
\text { training }\end{array}$} & \multicolumn{2}{|c|}{$\begin{array}{l}\text { Intensity of informal further } \\
\text { training }\end{array}$} \\
\hline & 2 & 3 & 4 & 5 \\
\hline & West & East & West & East \\
\hline $\begin{array}{l}\text { Structure of the workforce: } \\
-\quad \text { Proportion of skilled empl. } \\
\text { - } \quad \text { Proportion of employees with } \\
\quad \text { fixed term contract } \\
\text { - } \quad \text { Proportion of part time empl. }\end{array}$ & $\begin{array}{l}0.484^{*} \\
-0.390 \\
-0.565^{*}\end{array}$ & $\begin{array}{l}1.293 * * * \\
0.583 \\
-0.523\end{array}$ & $\begin{array}{l}0.608 * * \\
0.069 \\
0.098\end{array}$ & $\begin{array}{l}0.553 \\
0.497 \\
0.330\end{array}$ \\
\hline $\begin{array}{l}\text { Innovations: } \\
-\quad \text { Technological innovations } \\
-\quad \text { New materials } \\
-\quad \text { Product innovations } \\
-\quad \text { Organisational changes } \\
\end{array}$ & $\begin{array}{l}0.179 \\
0.143 \\
0.176 \\
0.697 * * *\end{array}$ & $\begin{array}{l}0.082 \\
0.398 * * \\
0.515 * * \\
0.558 * * *\end{array}$ & $\begin{array}{l}0.242 * * \\
0.484 * * \\
0.423 * * * \\
0.826 * * *\end{array}$ & $\begin{array}{l}0.372 * * \\
0.298 \\
0.388 * * * \\
0.950 * * *\end{array}$ \\
\hline $\begin{array}{l}\text { Work requirements } \\
\text { organization: } \\
\text { - Willingness and ability to } \\
\text { cooperate } \\
\text { - Holistic work organization } \\
\text { - Taking responsibility } \\
\text { - Participating in decisions } \\
\text { - Contributing to innovations } \\
\text { - Employability / career } \\
\text { development } \\
\text { - Information what happens in } \\
\text { - the enterprise } \\
\text { Autonomy }\end{array}$ & $\begin{array}{l}0.138 \\
0.031 \\
-0.011 \\
0.237 \\
0.130 \\
0.101 \\
0.269^{*} \\
0.191\end{array}$ & $\begin{array}{l}-0.045 \\
-0.008 \\
0.143 \\
0.535^{* *} \\
0.110 \\
-0.192 \\
0.356^{* *} \\
0.132\end{array}$ & $\begin{array}{l}0.210 \\
-0.144 \\
0.528 * * * \\
0.775 * * * \\
0.149 \\
0.089 \\
0.252 * * \\
0.176\end{array}$ & $\begin{array}{l}0.363 * * \\
-0.007 \\
0.806 * * * \\
0.421 * * \\
0.547 * * \\
-0.014 \\
0.102 \\
0.162\end{array}$ \\
\hline $\begin{array}{l}\text { HR problems } \\
-\quad \text { Labour turnover } \\
-\quad \text { Recruitment } \\
\end{array}$ & $\begin{array}{l}0.380 * * \\
-0.097\end{array}$ & $\begin{array}{l}-0.001 \\
-0.244 \\
\end{array}$ & $\begin{array}{l}0.257 \\
-0.033 \\
\end{array}$ & $\begin{array}{l}0.033 \\
-0.386 * *\end{array}$ \\
\hline $\begin{array}{l}\text { Size of enterprise / organizational } \\
\text { status: } \\
\text { Size (no. of empl. (log.)) } \\
\text { Status }\end{array}$ & $\begin{array}{l}0.321 * * * \\
0.159\end{array}$ & $\begin{array}{l}0.350 * * * \\
0.139\end{array}$ & $\begin{array}{l}0.233 * * * \\
0.169\end{array}$ & $\begin{array}{l}0.117 * * \\
0.140\end{array}$ \\
\hline $\begin{array}{l}\text { Sector: } \\
7 \text { sectors included }\end{array}$ & yes & yes & yes & yes \\
\hline $\mathrm{N}$ & 939 & 648 & 939 & 648 \\
\hline Pseudo-R ${ }^{2}$ & 0.067 & 0.083 & 0.119 & 0.140 \\
\hline
\end{tabular}

Dependent variable: Employer-provided further training intensity for forms of formal learning (column 2 and 3) and informal and work-integrated learning (column 4 and 5) in West German (column 2 and 4) and East German enterprises (column 3 and 5). Ordered probit. Software: STATA.

$* * *, * *, *$ significance on $1 \%-, 5 \%-, 10 \%$ levels.

Source: zsh: Competence development in German enterprises, own calculations. 


\section{References}

Bellmann, L. (2003): Datenlage und Interpretation der Weiterbildung in Deutschland, Bielefeld.

Bellmann, L./Düll, H./Leber, U. (2001): Zur Entwicklung betrieblicher Weiterbildungsaktivitäten. in: Reinberg, A. (Hrsg.): Arbeitsmarktpolitische Aspekte der Bildungspolitik, Beiträge zur Arbeitsmarkt- und Berufsforschung 245, Nürnberg, 97-123.

Bluhm, K. (1997): Problemfeld Kooperation: Entstehungsbedingungen regionaler Unterstützungsnetzwerke in der sächsischen Textilindustrie und im Maschinenbau, in: BISS public, 23, 24, 13-31.

Brinkmann, U. (2001): Von der Kaderabteilung zum Human Resource Management - (Irr-) Wege ostdeutscher Personalpolitik, in: Pawlowsky, P. /Wilkens, U.: Zehn Jahre Personalarbeit in den neuen Bundesländern. Transformation und Demographie. München und Mering: Rainer Hampp Verlag, 73-105.

Brussig, M./Leber, U. (2005): Integrating formal and informal learning activities in organisations. An empirical typology for German enterprises. Paper presented at the $21^{\text {st }}$ EGOS colloquium "Unlocking organisations". Berlin: Free University.

Brussig, M./Leber, U. (2004): Verringert informelle Weiterbildung bestehende Qualifikations-unterschiede? Aktuelle Ergebnisse einer Betriebsbefragung. in: WSIMitteilungen 1, 49-57.

Brussig, M./Leber, U. (2005): Betriebliche Determinanten formeller und informeller Weiterbildung im Vergleich, in: Zeitschrift für Personalforschung, 19, 1, 5-24.

Czarnitzki, D. (2003): Zum Ausmaß und den Determinanten der Produktivitätslücke ostdeutscher Unternehmen. in: Bellmann, L./Hujer, R.: Betriebliche Innovationen im Spiegel von Betriebsbefragungen. Beiträge zur Arbeitsmarkt- und Berufsforschung, Nürnberg, 139-166.

Dobischat, R./Seifert, H./Ahlene, E. (2003): Betrieblich-berufliche Weiterbildung von Gering-qualifizierten. Ein Politikfeld mit wachsendem Gestaltungsbedarf. in: Dobischat, R./Seifert, H./Ahlene. E.: Integration von Arbeit und Lernen. Erfahrungen aus der Praxis des lebenslangen Lernens, Berlin, 131-147.

Düll, H./Bellmann, L. (1999): Der unterschiedliche Zugang zur betrieblichen Weiterbildung nach Qualifikation und Berufsstatus. Eine Analyse auf der Basis des IABBetriebspanels 1997 für West- und Ostdeutschland. In: Mitteilungen aus der Arbeitsmarkt- und Berufsforschung 1, 99, 70-84.

Faust, M./Holm, R. (2001): Formalisierte Weiterbildung und informelles Lernen. Berufliche Kompetenzentwicklung in formellen und informellen Strukturen. Berlin, ABWF 69, 67-108.

Frieling, E./Kauffeld, S./Grote, S./Bernard, H. (2000): Flexibilität und Kompetenz: Schaffen flexible Unternehmen kompetente und flexible Mitarbeiter? Berlin a.o.: Waxmann.

Gerlach, K./Jirjahn, U. (2001): Employer Provided Further Training: Evidence from German Establishment Data. in: Schmollers Jahrbuch 2, 139-164.

Grünewald, U./Moraal, D./Drau, F./Weiß, R./Gnahs, D. (1998): Formen arbeitsintegrierten Lernens. Möglichkeiten und Grenzen der Erfassbarkeit informeller Formen der betrieblichen Weiterbildung, Berlin. 
Hitchens, DMWN/Wagner, K./Birnie, J. E. (1993): The comparative productivity of East German manufacturing: A matched plant comparison. Discussion paper FS I 93-310. Wissenschaftszentrum für Sozialforschung Berlin.

Kohler, U./Kreuter, F. (2001): Datenanalyse mit Stata. Allgemeine Konzepte der Datenanalyse und ihre praktische Anwendung, München/Wien.

Lang, R. (1995): Personalwesen im Osten vor und nach der Wende - Politisierte DeProfessionalisierung und marktwirtschaftliche Re-Professionalisierung?, in: Wächter / Metz: Professionalisierte Personalarbeit. Perspektiven der Professionalisierung des Personalwesens. München und Mering: Rainer Hampp Verlag, 85-110.

Lang, R./Wald, P. (2001): Brave new World? Kontinuität und Wandel im Personalmanagement in Ostdeutschland, in: Pawlowsky, P./Wilkens, U.: Zehn Jahre Personalarbeit in den neuen Bundesländern. Transformation und Demographie. München und Mering: Rainer Hampp Verlag, 19-35.

Mallok, J. (1996): Engpässe in ostdeutschen Betrieben. Technikausstattung, Technikeinsatz und Produktivität im Ost-West-Vergleich. Berlin: edition sigma.

Mallok, J./Fritsch, M. (1997): Die "Intelligenz" der Techniknutzung - zur Bedeutung des Maschinenparks und seiner Einsatzweise für betriebliche Leistungsfähigkeit. in: Zeitschrift für betriebswirtschaftliche Forschung 42, 2, 141-159.

March, J. G./Sproull, L. S./Tamuz, M. (1996): Learning From Samples of One or Fewer, in: Cohen, M./Sproull, L. S. (eds.): Organizational Learning. SAGE: Thousand Oaks a.o., $1-19$.

Pawlowsky, P. (2001): Personalentwicklungsstrategien und die demographische Falle in den neuen Bundesländern. in: Pawlowsky, P./Wilkens, U.: Zehn Jahre Personalarbeit in den neuen Bundesländern: Transformation und Demographie, München und Mering, $107-120$.

Rothfels, J./Müller, G./Wölfl, A. (1998): Determinanten der Produktivitätslücke in Ostdeutschland - Teil II. in: Wirtschaft im Wandel 2/1998, 15-21.

Rothfels, J./Ragnitz, J./Wölfl, A. (1998): Determinanten der Produktivitätslücke in Ostdeutschland - Ergebnisse einer Tagung am IWH - Teil I. in: Wirtschaft im Wandel 1/1998, 4-11.

Starbuck, W. H. (1996): Learning by Knowledge-Intensive Firms, in: Cohen, M./Sproull, L. S. : Organizational Learning. SAGE: Thousand Oaks a.o., 484-515.

Staudt, E./Kley, T. (1998): Formelles Lernen - informelles Lernen - Erfahrungslernen. Wo liegt der Schlüssel zur Kompetenzentwicklung von Fach- und Führungskräften? Berufliche Kompetenzentwicklung in formellen und informellen Strukturen. ABWF 69, 227-275.

Wilkens, I./Leber, U. (2003): Partizipation an beruflicher Weiterbildung. Empirische Ergebnisse auf Basis des Sozio-oekonomischen Panels, in: Mitteilungen aus der Arbeitsmarkt- und Berufsforschung, 36, 3, 329-337.

Zwick, T. (2004): Weiterbildungsintensität und betriebliche Produktivität. in: Zeitschrift für betriebswirtschaftliche Forschung, 74, 7, 651-668. 